\title{
THE POEMS OF THOMAS KENNEDY OF MARYLAND
}

\author{
BY ROBERT MEHLMAN \\ Mr. Mehlman is Associate Professor of English \\ at Trenton State College
}

HOMAS KENNEDY, an obscure figure in the history of
American literature, is ignored in the major bibliographies
and biographies, ${ }^{1}$ and even in a work of such limited scope as The Representative Authors of Maryland is given only an incomplete, single-line reference: "Kennedy, Thomas, Poems, I 8 I6." Yet Kennedy's Poems and his Songs of Love and Liberty (Washington City, I 8I7) were both published at a time when "not quite one-third of the publications issued in the United States came from American writers." "Membership in this rather small group of American writers would seem to make at least one examination of his works necessary. In addition, Kennedy's poems record the ordinary experiences of life: love, birth, and death, during a now almost legendary era of our nation. Finally, his poems celebrate a passion for the United States as a symbol of liberty which it is difficult for us to understand at a time when our national purpose has to be redefined. Kennedy's poems are historical documents as well as works of literature.

The devotion to liberty which Kennedy expressed in his poems and in his life was an outgrowth of his Scottish heritage and his Presbyterian upbringing. ${ }^{4}$ He was born in Paisley, Scotland, on No-

${ }^{1}$ Neither the Cyclopedia of American Literature, ed. E. A. Duyckinck and G. L. Duyckinck, 2 vols. (New York, I 855), Supplement (New York, I 866), nor the Library of American Literature, ed. E. C. Stedman and E. M. Hutchinson, i i vols. (New York, I 888-9o) lists him.

2 Henry E. Shepherd (New York, I9II), p. 2 I6. Although Kennedy's book is dated Washington City, 1816 on the title page, the date March 4, 1817 after the envoi shows that the book must have been published in that year.

${ }^{3}$ Charles A. Beard and Mary R. Beard, The Rise of American Civilization (New York, 1930), p. 764 .

4 The following biographical information is derived from Emanuel Milton Altfeld, The Jew's Struggle for Religious and Civil Liberty in Maryland (Baltimore, 1924), pp. 15-27, except where noted. Altfeld's study is the most complete examination of Kennedy's political career, and, so far as I have been able to check, is accurate. Unfortunately, Altfeld does not document his sources. 
vember 29, I776, the son of William and Grizal Kennedy. The importance of the lesson of his parents, "that the paths of virtue were also the only paths to peace and true pleasure" (p. 2$)^{5}$ and the lasting influence of that lesson may be seen in the long, philosophical poem, "What Makes a Mortal Great?". Written after Kennedy had been away from home for at least seven years, the poem discusses and discards power and grandeur (wealth) as "The nearest-the clearest / Plain path to peace of mind." The stoic objective of the poem is resolved in the sixteenth stanza, a stanza which perhaps also explains much of the appeal of the United States, for Kennedy, as a land which placed the worth of the individual above "hereditary worth":

Then who are great? the good alone;

Yes real greatness is their own,

Whate'er their station, sphere

Plac'd in a cottage, or a court,

The child of fortune or her sport,

Their names shall ay be dear.

Illustrious their descent and birth,

Peace-honor on them wait;

The only nobles of the earth,

The good are ever great.

The Portal-immortal

Of glory opens wide

Before them-adore them

And follow where they guide.

The "man of goodness" has his eyes fixed on eternal values, he is a friend to freedom, he accepts and fulfills his responsibilities to his family and nation, and, in the end, "Death is to him a welcome sleep." Kennedy tried to live up to this ideal faithfully.

During his childhood in Scotland, Kennedy could hardly escape acquaintance with the poems and songs of Allan Ramsay (I686I 758), Robert Ferguson (I750-I774), and Robert Burns (I759I796); all three poets are mentioned in the humorous prologue to Poems. Burns especially was admired by Kennedy, for his lyric gifts as well as for his romantic celebration of the simple life. The song

${ }^{5}$ All citations are from Poems (Washington City, 1816) unless otherwise noted. The copy of Poems used for this article is in the Special Collections of the Rutgers University Library. 
"The Happy Cottage," for example, is reminiscent of Burns's "The Cotter's Saturday Night." The first stanza of the song depicts the pleasures of life in an essentially benevolent world of nature:

While the scenes of the Town, fame, grandeur and wealth,

Are by many preferr'd to the blessings of health,

In this Happy Cottage far rather I'd live,

Enjoying those pleasures that Nature can give,

A cottage so pleasant, will constantly prove

The abode of sweet peace, the seat of true love. ${ }^{6}$

Although Kennedy admired the unaffectedness of Burns, whom he characterized as 'void of art,' he could not avoid dressing the subject, using an adjective for each noun.

Armed with the ethics inculcated by his parents, and accompanied by a knowledge of and admiration for the poems of his fellow countrymen, Kennedy left Glasgow April i 8, I 796, on the ship Britannia. Even before leaving Scotland, he conceived an affection for the United States. The first poem of his collection opens with praises of America, "a country which at that time he had no expectations of ever visiting," he confesses in a note. His older brother, Matthew, had already gone to the United States, and, after a silence of twelve years, was believed dead. However, in I 795 a letter from Matthew was brought to his parents, encouraging emigration, and Thomas and John embarked for Georgetown, although on different ships.

When Kennedy arrived at Georgetown, he was the first to leap ashore, "glad, once more to tread on solid ground-and that too in the land of liberty." In a remarkable coincidence, the first stranger Kennedy approached was his long lost brother, Matthew. Together, they ate and went to view Washington, then a city of six buildings.

Kennedy's journeys in the environs of Washington may be traced through his poems. He worked first as a bookkeeper for a merchant in Georgetown, then for a contractor who built the bridge across the Potomac at Little Falls. "The Meeting of Virginia and Maryland," a dialogue between personifications of the two states, commemorates this joining of the two states for the first time. The dream-vision allegory in heroic couplets voices Kennedy's characteristic, though recent, patriotism in the culminating song, set to the tune of Philip

${ }^{6}$ Songs of Love and Liberty, pp. 5 and 6. 
Phile's "The President's March." Maryland sings one stanza of the song, Virginia another; then together they sing:

O! Freedom-bless our land with peace,

Let War-let discord ever cease,

The Golden age again revive,

The Golden age again revive,

$\mathrm{O}$ ! Hasten the expected time,

When ev'ry nation, color, clime,

Shall see oppressions pow'r decay,

Shall love thy laws and own thy sway,

O! Freedom rise, complete the plan,

Restore his native rights to man,

Heavenly Goddess unto thee,

All the sons of Liberty,

All that own fair virtues sway,

Unto thee shall homage pay.

Shortly after the completion of the bridge, Kennedy was employed by the Potomac Navigation Company, and continued to frequent the area around Great Falls, Virginia. There he met Miss Rosamond Thomas, ${ }^{8}$ a visitor from Frederick, Maryland, fell in love, and eventually married her. Yet even in the sonnet written on his wedding day, Kennedy could not forget his beloved nation, and concluded the poem with a witty political figure:

And O! may love still o'er the day preside,

That saw the sacred union ratified.

${ }^{7}$ Composed probably in 1789 , the march was reputedly played at the passing of Washington over Trenton bridge on his way to New York for his inauguration. "Hail Columbia," by which title the march is most commonly known, was adapted by Joseph Hopkinson, who wrote the words, and was sung first by Gilbert Fox at the Philadelphia Theatre on the evening of April 25, 1798. See The Music that Washington Knew, ed. William Arms Fisher (Boston, 1931), pp. 14-19, and Music Associated with the Period of the Formation of the Constitution and Inauguration of George Washington, ed. John Trasker Howard and Eleanor S. Bowen (Washington, [1937?]), p. 2 I. In Kennedy's Songs of Love and Liberty, p. 35. The second line of the third stanza of "The American Blues" may echo "Hail Columbia":

Remember the heroes in liberty's cause

Who fought and who bled with a brave resolution,

Their patriot names with deserved applause

Will be gratefully honor'd till times dissolution.

This song was set to the tune "To Anacreon in Heaven."

${ }^{8}$ Called "Harris" in the poem. "Harris" was probably her middle name, since Kennedy's eldest surviving daughter was named Rosamond Harris. Another daughter was named Rosamond Thomas. 
Kennedy's devotion to the cause of freedom was more than lipservice, however, and his fight against religious prejudice is a noble, if little-known, chapter in American history. After his marriage, Kennedy moved to Maryland, where he was elected to the state legislature as a delegate from Washington County in 1817 . He immediately began to study the question of religious inequity in the laws of Maryland.

In I 779 the Maryland legislature had passed a law which prohibited anyone who would not swear an oath of allegiance to Christianity from holding any office, civil or military, under the state government. ${ }^{9}$ Although Solomon Etting, Bernard Gratz, and other prominent Jews of Baltimore had petitioned for the abolition of the law in I797, they were unsuccessful. Kennedy, although he confessed in an 1818 address to the House of Delegates "that he had not the slightest acquaintance with any Jew in the world," made the elimination of this restriction his life work.

On December 9, I818, Kennedy introduced a bill to consider the justice and expediency of "placing the Jewish inhabitants of Maryland on an equal footing with Christians, ${ }^{, 10}$ and stated, in a committee report, that religion was a question between man and his Creator, not between a man and his government. The bill was defeated in both I8I9 and I820. As a result of his agitation, Kennedy was defeated for re-election in I 82 I and I 823 , and was assailed as a "Judas" and "enemy of Christianity."

During the time that he was out of office, Kennedy wrote a long poem in heroic couplets, "To the Children of Israel in Maryland," which he sent to the leaders of the Jewish community of Baltimore. The poem is really a sermon in verse, which traces the persecution of the Jews from Biblical times to the nineteenth century, and which condemns Christians, who should follow the Golden Rule, for forgetting their "precious precept." Kennedy recognizes that many of "Israel's tribes shall seek their native land," but asks:

When fix'd forever is your country's fate,

Adorn'd with all that's good, and all that's great,

Will no soft sighs some former scenes recall?

\footnotetext{
${ }^{9}$ Matthew Page Andrews, History of Maryland: Province and State (Garden City, N. Y., I929), p. 450.

${ }^{10}$ Ibid., p. $45 \mathrm{I}$.
} 
Will no kind tears from eyes of friendship fall?

Is there no land on Earth will cause regret?

Is there no land you never can forget?

While fond remembrance cry-We love her yet? ${ }^{11}$

$\mathrm{He}$ answers his question by envisioning a land "That shall unite Gentiles and Jews in one- / Home of the Brave-the Land of Washington."

In his argument for the extension of civil rights, Kennedy was supported by Article VI of the Federal Constitution as well as by the recently adopted First Amendment. Eventually, the weight of an increasingly insistent public opinion which recognized the importance and influence of certain Jews in Baltimore, "and of actual hardships arising out of their civil disabilities," tipped the balance. ${ }^{12}$ In a speech before the legislature, Kennedy urged:

Let us then pass this bill, let us pass it unanimously. We will never repent it, even on a dying pillow. It will comfort us to think that we have done at least one good act in our lives, that we have been instrumental in establishing religious freedom in Maryland, that we have broken the yoke of superstition and prejudice and let the oppressed go free, and that we have caused happiness to many an anxious heart. ${ }^{13}$

Although the "Jew Bill" was defeated at that time, it was brought up in each succeeding session. Finally, on January 5, I 826, the last day of the session, the bill passed.

Kennedy continued to enjoy public life after the passage of the bill, and in 1827 was elected to the State Senate as a Jacksonian Democrat. The growth of his sympathies for Jackson may be seen in the titles of his songs: "The Land of Freedom," gave way to "The New Orleans March," and that was succeeded by "Jackson Is the Boy." In a speech at the Jackson meeting held at the courthouse in Hagerstown, Kennedy mentioned that he was experiencing difficulty with his friends because of his position that John Quincy Adams should have declined the presidency in favor of the popular vote for Jackson. Typically, Kennedy added that Adams would have thus assured himself of immortality. ${ }^{14}$ Still active in public life, Kennedy

11 Cited by Altfeld, pp. 2 I-26, evidently from a manuscript.

12 Andrews, p. 451 . ${ }_{13}$ Cited by Altfeld, p. I 64.

${ }^{14}$ Speech of Thomas Kennedy, Esquire, at the Jackson Meeting Held at the CourtHouse in Hagers-Town. August 4, 1827 (Hagerstown, [I827?]), p. 7 . 
was struck down in a cholera epidemic, and died on October I7, I $830 .^{15}$

Kennedy's verses may be divided, by subject, into two broad areas: political and personal. Like Joel Barlow's "Columbiad," Kennedy's political verse "typified three of the most important national characteristics of the time,-love of country, enthusiasm for republican principles, and emphasis upon the ethical in its application to national life." ${ }^{16}$ Like Barlow too, Kennedy seems to have viewed the establishment of the United States as of epic significance, although Kennedy never tried to write an American epic. His adulation of George Washington appears in "Verses Composed on the Fourth of July, I 80r," and the list of Revolutionary heroes congruous with such an epic concept, may be seen in the eighth stanza:

And see what numerous worthies throng,

In order grand-and lo! among

The patriot ranks-a Warren-Green-

A Hancock-Adams-Mercer's, seen, Montgomery and M'Pherson brave,

Who early found an honour'd grave,

Franklin and Rittenhouse attend,

The modest Jefferson-their friend.

In his political verse, Kennedy put forth his rational love of freedom, for, as he expressed it in "Epistle to $\mathrm{S}^{* * * * *} \mathrm{R} * * * * * * *$, Esq.," "Reason and knowledge were design'd, / To be our guides."

Kennedy's political verse shows his development as an American. The contrast between the first of his Poems, "Ode: Composed for the 6th Anniversary of the French Revolution, July I4th, I 795," and the last, "Ode: On the Conflagration at Washington City, Au-

${ }^{15}$ An interesting literary anecdote about Dr. Howard Kennedy, a son of Thomas Kennedy, is related in Maryland: A Guide to the Old Line State, comp. workers of the Writer's Program of the Work Projects Administration in the State of Maryland (New York, 194I), p. 289 :

About three days after the Battle of Antietam . . . as Mrs. Kennedy and her small daughter Annie were watching the dreary procession of wounded pass by, a badly wounded Union officer collapsed before their door. Mr. Kennedy ... had the young man brought into the house and cared for him. The officer was Oliver Wendell Holmes, Jr., later a Justice of the United States Supreme Court. His father, after a frantic search of the battlefield, finally found his son whom he had given up for dead. He commemorated the event in the poem "My Search for the Captain."

${ }_{16}$ William Bradley Otis, American Verse: ${ }_{1625-1807}$ (New York, 1909), p. 170. 
gust 24, I 8 I 4," makes this identification clear. In his first poem, Kennedy writes about America as an outsider:

Thrice welcome July! Patriots, say,

Which is the most auspicious day,

In this high favor'd month, to man?

Shall we forget? No, we ne'er can,

The happy time,

The day sublime!

The Glorious Fourth on which a people brave,

Broke from a pow'r who wish'd them to enslave

Announced the Rights of Man, and did a nation save.

"Happy, Happy, Happy," day

America

That gave to thee

Rough Independence and sweet Liberty!-

By the time of the last poem, after having lived through the War of $\mathrm{I} 8 \mathrm{I} 2$, Kennedy writes with indignation of the outrages committed by the British on "our coasts":

Britain, what are thy sons become?

A race of robbers plundering band;

That raise on high the savage brand;

Along our coasts like outlaws roam.

The refrain, "But Washington sav'd us in times that are past, / And the flames of his city shall save us at last," shows Kennedy's ultimate sense of involvement with the destiny of the nation.

So pervasive is Kennedy's patriotism that it invades other areas of experience. The conclusion of his wedding sonnet "To Harris" has already been cited in this respect. In the middle of an "Elegy to the Memory of Trusty, the Author's Dog," the poet turns from his description of the virtues of the subject of the poem to remark:

On bare suspicion of offence Has Trusty dy'd.

All tyrants in each clime we see

On this important point agree,

That might is right.-Necessity,

But Trusty what is that to me,

Their plea-their reason,

At this sad season. 
And the facetious "Address to a Rabbit: Caught in the Harvest Field, July 5, I 809" is really a disquisition on the benefits of freedom.

The personal poems of Kennedy are, apart from historical considerations, the most interesting part of his work. It is difficult to follow disinterestedly the progress of a love affair demonstrated in such poems as: "A Woman," "To a Young Female Friend," "Hope and Fear or What Might Be," "To a Locket," "To a Young Lady," "Bad Horsemanship," "Farewell," "To Harris on Her Birthday," "The Kiss," and "The Sigh that You Heard," especially when the affair ends in marriage.

At the other end of the scale, it is difficult to ignore the touching quality of the lyrics which were brought forth by the experience of sickness and death within the family. The fact that the "Hymn: Wrote During Harris's Sickness" is followed by a "Hymn of Thanks, on the Recovery of Harris" makes the understatement of both poems affecting. And when the very poem in which thanks was given for "Amelia given-my Harris sav'd" is followed by "To the Memory of Amelia Thomas, (the author's second daughter,) who, after a life of anguish, died Sept. 26th, I80 , aged i 5 days," the conventional diction of the opening stanza does not seem so very conventional after all:

Amelia! art thou gone? my heart-O! no, Death surely cannot claim his prey so soon;

He will not strike-he will not take thee so, Thou hast not seen the light a single moon.

Perhaps the best of Kennedy's poems, "On the Death of William Thomas, the Author's Son," also engages the sympathies of the reader because of the emotional appeal of the subject. Nevertheless, a note of genuine despair is struck in the second stanza mainly because of the placement of the exclamations:

Another heavy loss, a stroke severe,

Takes my attention from the bustling train,

Draws forth fond nature's sigh, affection's tear, And calls for fortitude to bear the pain.

My William Thomas! O! thou darling boy, The sweetest cherub that on earth e'er smil'd, Thou was thy "father's pride, thy mother's joy," And art thou lost forever, O! my child. 
Since Kennedy dwells so long on the bereavement felt for the loss of the child, his resolution, "Him-angels to the blest abodes have borne, / Though here we mourn and weep, he's happy there," seems unconvincing, a failure which makes the poem even more poignant (though less artful) than it might otherwise have been.

During his lifetime, Kennedy evidently attained some reputation as a versifier, for much of his personal verse seems to have been composed at the request of admirers. Included in Poems, for example, is an "Address" (a toast) delivered at an anniversary celebration of the Battle of New Orleans, and some lines about a rose, requested by Miss Matilda S. The poet used these opportunities to exercise his exuberant sense of humor. The "Ode to the Mammoth Cheese," written on the occasion of the presentation of a half-ton cheese to Thomas Jefferson by the citizens of Cheshire, Massachusetts, begins:

Most excellent, far fam'd and far fetch'd Cheese!

Superior far in smell, taste, weight, and size,

To any ever form'd 'neath foreign skies,

And highly honour'd-thou wert made to please

The Man belov'd by all-but stop a trice,

Before he's prais'd, I too must have a slice.

Kennedy wrote on other gustatory subjects as well; "To a Young Lady, Who Sent the Author a Very Nice Frog" is followed by the illuminating note that "Frogs_-particularly those of the Bull kind, are at this time all the rage at barbacues [sic]. \&c." Kennedy's sense of humor is also displayed in the ribald poem "Did You See My Agility":

As John and Bess, a youthful pair,

Were riding to a neighb'ring fair,

The maiden's horse got somehow scar'd,

And up the foolish poney rear'd.

Poor Betsey lost her seat and hold,

But what John saw shall not be told,

She was laid low upon the ground,

Yet, thanks to fate, without a wound.

Rising like a lark upon the wing,

She mounted with a dex'trous spring,

When seated-smiling then said she,

"Did you see-my agility?" 
John look'd so queer and scratch'd his head,

"Betsey-I cant say but I did,

"Though by that name, (he laughing swore,)

I never heard it call'd before."

In his poetry, Thomas Kennedy, like many of his contemporaries, vacillated between neo-Classicism and Romanticism. He was in the backwash of a tradition, the mainstream of which gave rise to the works of Grayson, Timrod, Hayne, and Lanier, on the one hand, and to the popular, sentimental works which Twain satirized in the poems of Emmeline Grangerford, on the other hand. If he had come into contact with any of the literary movements of his day, Kennedy would probably not have fallen into such complete obscurity, for his poems are not so poorly wrought as to make them worthless. Yet he is also one of "the lesser writers of patriotic verse who . . . must ... be judged from the standpoint rather of the vision than of the song." ${ }^{17}$ In his poems, Kennedy praised his adopted land; in his life he worked to make the freedom which that nation symbolized to him available to all.

17 Ibid. 